Check for updates

Cite this: RSC Adv., 2018, 8, 2777

Received 23rd November 2017 Accepted 6th January 2018

DOI: 10.1039/c7ra12713h

rsc.li/rsc-advances

\section{Mechanism studies of addition reactions between the pyrimidine type radicals and their $3^{\prime} / 5^{\prime}$ neighboring deoxyguanosines $\uparrow$}

\author{
Shoushan Wang, (D) ab Min Zhang, ${ }^{\mathrm{b}}$ Peng Liu, (D) ${ }^{\mathrm{b}}$ Shilei Xie, (D) ${ }^{\mathrm{b}}$ Faliang Cheng*b \\ and Lishi Wang (iD *a
}

To clarify the biologically significant sequence effect existing in the formation of the pyrimidine-type radicals induced DNA intrastrand cross-links, addition mechanisms between the uridine-5-methyl $\left(\cdot \cup_{\mathrm{CH}_{2}}\right)$, 6-hydroxy-5,6-dihydrothymidine-5-yl $\left({ }^{\circ} \mathrm{T}_{6 \mathrm{OH}}\right)$, and 6-hydroxy-5,6-dihydrocytidine-5-yl $\left({ }^{\circ} \mathrm{C}_{6 \mathrm{OH}}\right)$ radicals and their $3^{\prime} / 5^{\prime}$ neighboring deoxyguanosines $(\mathrm{dG})$ are explored in the present study employing the model $5^{\prime}-\mathrm{G}\left({ }^{\circ} \mathrm{U}_{\mathrm{CH}_{2}}\right)-3^{\prime}, 5^{\prime}-\left({ }^{\circ} \cup_{\mathrm{CH}_{2}}\right) \mathrm{G}-3^{\prime}, 5^{\prime}-\mathrm{G}\left({ }^{\cdot} \mathrm{T}_{6 \mathrm{OH}}\right)-3^{\prime}, 5^{\prime}-\left({ }^{\circ} \mathrm{T}_{6 \mathrm{OH}}\right) \mathrm{G}-3^{\prime}, 5^{\prime}-\mathrm{G}\left({ }^{\circ} \mathrm{C}_{6 \mathrm{OH}}\right)-3^{\prime}$, and $5^{\prime}-\left({ }^{\circ} \mathrm{C}_{6 \mathrm{OH}}\right) \mathrm{G}-$ $3^{\prime}$ sequences. It is found that the $5^{\prime} \mathrm{G} / \mathrm{C}_{8}$ additions of the three radicals are all simple direct one-step reactions inducing only relatively small structural changes, while a conformational adjustment involving orientation transitions of both nucleobase moieties and twisting of the DNA backbone is indispensable for each $3^{\prime} \mathrm{G} / \mathrm{C}_{8}$ addition. Furthermore, markedly positive reaction free energy requirements are estimated for these conformational transformations making the $3^{\prime} \mathrm{G} / \mathrm{C}_{8}$ additions of the three radicals thermodynamically much more unfavorable than the corresponding $5^{\prime} \mathrm{G} / \mathrm{C}_{8}$ additions. Such essential conformational adjustments along the $3^{\prime} \mathrm{G} / \mathrm{C}_{8}$ addition paths that structurally greatly influence the local DNA structures and thermodynamically substantially reduce the addition efficiencies may be the reasons responsible for the differences in the formation yields and biological consequences of the pyrimidinetype radicals induced DNA intrastrand cross-link lesions.

\section{Introduction}

Hydroxyl radicals $\left(\mathrm{OH}^{*}\right)$, which can be generated endogenously via transition metal ion mediated Fenton-type reactions ${ }^{1}$ and exogenously by ionizing radiation, ${ }^{2}$ are able to cause numerous types of DNA lesions, including single-base modifications, strand-breaks, abasic sites, DNA intra- and interstrand crosslinks. ${ }^{3-5}$ DNA lesions that are not repaired in time are mutagenic, genotoxic, and cytotoxic, which are capable of giving rise to cell apoptotic death, and thus are believed to be associated with aging.6 and a variety of human diseases, such as neurological disorders, ${ }^{7}$ cardiovascular diseases, ${ }^{8}$ and cancers. ${ }^{\mathbf{9}, 10}$

DNA intrastrand cross-links, in which two neighboring nucleobases in the same strand are linked together by a single covalent bond, have attracted great concern and have been continuously investigated in the past two decades. ${ }^{\mathbf{1 1 - 3 3}}$ Since the

${ }^{a}$ School of Chemistry and Chemical Engineering, South China University of Technology, Guangzhou 510641, People's Republic of China. E-mail: wanglsh@scut. edu.cn

${ }^{b}$ Guangdong Engineering and Technology Research Center for Advanced Nanomaterials, School of Environment and Civil Engineering, Dongguan University of Technology, Dongguan 523808, People's Republic of China. E-mail: chengfl@dgut. edu.cn

$\dagger$ Electronic supplementary information (ESI) available. See DOI: $10.1039 / \mathrm{c} 7 \mathrm{ra} 12713 \mathrm{~h}$ seminal finding of the $\mathrm{G}(8-5 \mathrm{~m}) \mathrm{T}$ intrastrand cross-link (where the $\mathrm{C}_{8}$ atom of guanine is covalently tethered to the 5-methyl carbon atom of its $3^{\prime}$ neighboring thymine, partial atomic
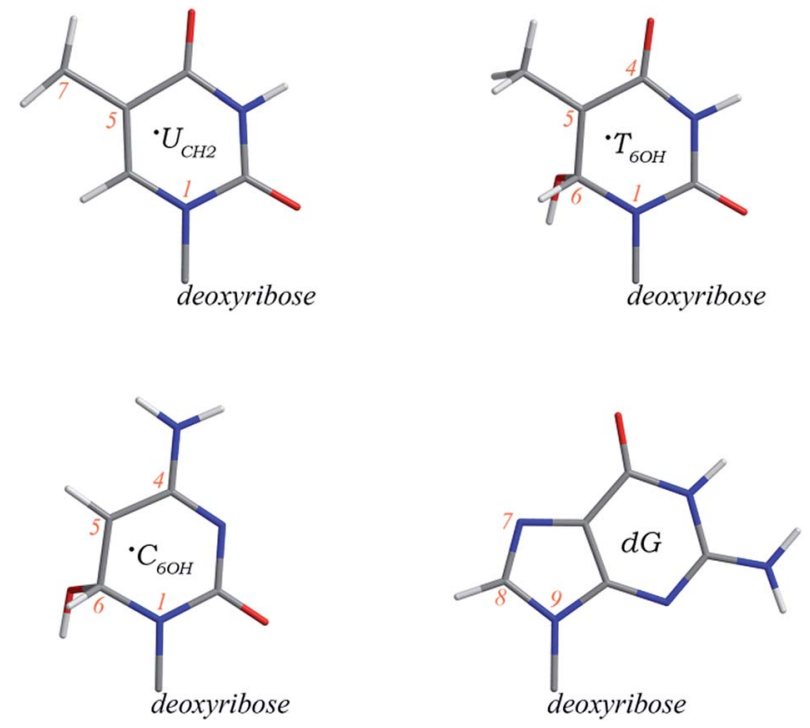

Scheme 1 Schematic structures and partial atomic numberings of the $\cdot \mathrm{U}_{\mathrm{CH}_{2^{\prime}}} \mathrm{T}_{6 \mathrm{OH}}$, and ${ }^{\circ} \mathrm{C}_{6 \mathrm{OH}}$ radicals as well as deoxyguanosine. 
numberings of related species are shown in Scheme 1) in Xirradiated deoxygenated aqueous solution of d(CpGpTpA) oligomer, ${ }^{11}$ more than 15 DNA intrastrand cross-links have now been isolated. ${ }^{\mathbf{1 2 - 2 3}}$ Formation of DNA intrastrand cross-links having experimentally definitely identified structures is proposed as a single-radical event. ${ }^{5}$ The $\mathrm{OH}^{*}$ radical produced via endogenous or exogenous path can either add to the $\mathrm{C}_{5}=\mathrm{C}_{6}$ double bond or abstract a hydrogen from the 5-methyl group of pyrimidine bases forming the corresponding secondary radicals, which can then attack their surrounding purine nucleosides (mainly the deoxyguanosine) eventually leading to diverse DNA intrastrand cross-links. ${ }^{34}$ UV-light irradiation experiments of DNA fragments modified by related photolabile precursors confirmed the reasonability of this reaction mechanism, and many other DNA intrastrand cross-links were further detected..$^{24-33,35,36}$ One point to be noted is that an obvious sequence effect is observed in the formation yields of these pyrimidinetype radicals induced DNA intrastrand cross-links, namely the yields of the $5^{\prime}$-purine-pyrimidine- $3^{\prime}$ cross-links are considerably higher than those of the corresponding $5^{\prime}$-pyrimidinepurine- $3^{\prime}$ cross-links. ${ }^{15-17,20,26,28,29,31}$ This sequence effect was only simply and tentatively attributed to the difference in the distances between the two bonding atoms, the shorter the distance is, the higher the yield is, ${ }^{15,16,28}$ and convincing explanations are still unclear and lacking. Exploring the addition paths of the pyrimidine-type radicals to their $3^{\prime} / 5^{\prime}$ neighboring purine nucleosides may offer some reasonable and valuable insights into this sequence effect.

Apart from markedly interrupting DNA replication and significantly decreasing the efficiency and fidelity of nucleotide incorporation, ${ }^{16,18,19,35,37,38}$ DNA intrastrand cross-links are also able to lead to substantial targeted and semitargeted base transition and transversion mutations, ${ }^{18,19,21,38}$ with the mutational frequencies induced by the $5^{\prime}$-pyrimidine-purine- $3^{\prime}$ crosslinks greatly higher than those induced by the $5^{\prime}$-purinepyrimidine- $3^{\prime}$ cross-links, ${ }^{21}$ indicating that a sequence effect may also exist in the biological consequences of DNA intrastrand cross-links. The unique structures of DNA intrastrand cross-links of different types are tentatively speculated to be responsible for these observations. ${ }^{16,18,19}$ On the other hand, DNA intrastrand cross-links can resist, to some extent, the excision repair of DNA nucleotide excision repair system. ${ }^{39,40}$ Again, the repair efficiencies were proposed to be correlated with the different degrees of structural distortions of DNA double helixes induced by different types of DNA intrastrand cross-links. ${ }^{40-42}$ Thus, exploring the probable structures and formation mechanisms of different types of DNA intrastrand cross-links are much helpful for better understanding of these biological consequences. However, recent theoretical efforts were mainly focused on the studies of formation paths of $5^{\prime}$ purine-pyrimidine- $3^{\prime}$ type cross-links and their influences on DNA double helical structures. ${ }^{41-48}$ To the best of our knowledge, probable formation mechanisms of the corresponding $5^{\prime}$ pyrimidine-purine- $3^{\prime}$ type cross-links are scarcely investigated.

On the basis of the above discussions, reaction paths of the $\cdot \mathrm{U}_{\mathrm{CH}_{2}},{ }^{\cdot} \mathrm{T}_{6 \mathrm{OH}}$, and ${ }^{\circ} \mathrm{C}_{6 \mathrm{OH}}$ radicals adding to the $\mathrm{C}_{8}$ site of their $3^{\prime} /$ $5^{\prime}$ neighboring deoxyguanosines are studied here. For each radical, different from the simple direct one-step $5^{\prime} \mathrm{G} / \mathrm{C}_{8}$ addition, a conformational transformation not only structurally significant but also thermodynamically markedly unfavourable is firstly required for the $3^{\prime} \mathrm{G} / \mathrm{C}_{8}$ addition, which may be the possible reasons leading to different formation yields and biological consequences of the corresponding DNA intrastrand cross-links.

\section{Computational details}

Dinucleoside monophosphates are demonstrated to be relevant models for investigations of DNA intrastrand crosslinks, ${ }^{47}$ and thus the models $5^{\prime}-\mathrm{G}\left({ }^{\cdot} \mathrm{U}_{\mathrm{CH}_{2}}\right)-3^{\prime}, 5^{\prime}-\left({ }^{\cdot} \mathrm{U}_{\mathrm{CH}_{2}}\right) \mathrm{G}-3^{\prime}, 5^{\prime}-$ $\mathrm{G}\left({ }^{\bullet} \mathrm{T}_{6 \mathrm{OH}}\right)-3^{\prime}, 5^{\prime}-\left({ }^{\cdot} \mathrm{T}_{6 \mathrm{OH}}\right) \mathrm{G}-3^{\prime}, 5^{\prime}-\mathrm{G}\left({ }^{\cdot} \mathrm{C}_{6 \mathrm{OH}}\right)-3^{\prime}$, and $5^{\prime}-\left({ }^{\cdot} \mathrm{C}_{6 \mathrm{OH}}\right) \mathrm{G}-3^{\prime}$ sequences were employed here, which were constructed based on the canonical $5^{\prime}-\mathrm{GT}-3^{\prime}, 5^{\prime}-\mathrm{TG}-3^{\prime}, 5^{\prime}-\mathrm{GC}-3^{\prime}$, and $5^{\prime}-\mathrm{CG}-3^{\prime}$ sequences extracted from an experimental X-ray crystal structure of a B-DNA (PDB code: 5FMP). One hydrogen atom was deleted from the 5-methyl group of the $\mathrm{T}$ moiety or a hydroxyl group was added on the $\mathrm{C}_{6}$ site of the $\mathrm{T}$ or $\mathrm{C}$ moiety, the two phosphodiester bonds were capped with methyl groups to prevent the formation of parasitic hydrogen bonds, ${ }^{49}$ and a sodium ion was inserted between the two phosphate oxygens to mimic the physiological conditions. ${ }^{50}$ The M06-2X functional combined with the standard 6$31 \mathrm{G}(\mathrm{d}, \mathrm{p})$ basis set was used for all geometry optimizations and energy calculations. The M06-2X/6-31G(d,p) level of theory has been proved to be reliable for studies of DNA intrastrand cross-links, ${ }^{\mathbf{4 4 , 5 1}}$ and actually is recommended to explore the structure and/or reactivity of a dinucleoside monophosphate. ${ }^{50}$ All structures obtained were shown to be minimum or first-order saddle points on potential energy surfaces by frequency analyses. Intrinsic reaction coordinate calculations were performed to confirm the connections of each transition state with its corresponding reactant and product. The IEF-PCM formalism ${ }^{52}$ with a dielectric constant $\varepsilon$ $=78.4$ was employed to approximate the solvated environment. ${ }^{47,50}$ Related kinetic and thermodynamic characteristics for each reaction process were estimated on the basis of Gibbs free energies calculated in the rigid-rotor harmonic oscillator approximation at $T=298 \mathrm{~K}$ and $p=1$ atm. Geometry optimizations and energy calculations were carried out using Gaussian 09 package, ${ }^{53}$ and structures of all stationary points were analysed employing the X3DNA suite of programs. ${ }^{54}$

\section{Results and discussion}

Formation of DNA intrastrand cross-links is generally a threestep reaction, ${ }^{\mathbf{4 1 4 5 - 4 7}}$ consisting of (step 1) formation of the highly reactive pyrimidine-type radicals, (step 2) additions of these radicals to their $3^{\prime} / 5^{\prime}$ neighboring purine nucleosides (mainly deoxyguanosine), and (step 3) formation of the final closed-shell intrastrand cross-links. The present study is mainly focused on the step 2, namely exploring the probable addition paths of ${ }^{\circ} \mathrm{U}_{\mathrm{CH}_{2}},{ }^{\cdot} \mathrm{T}_{6 \mathrm{OH}}$, and ${ }^{\circ} \mathrm{C}_{6 \mathrm{OH}}$ radicals to the $\mathrm{C}_{8}$ site of their $3^{\prime} / 5^{\prime}$ neighboring deoxyguanosines. 
Additions of the ${ }^{\circ} \mathrm{U}_{\mathrm{CH}_{2}},{ }^{\cdot} \mathrm{T}_{6 \mathrm{OH}}$, and ${ }^{\circ} \mathrm{C}_{6 \mathrm{OH}}$ radicals to the $\mathrm{C}_{8}$ site of their $5^{\prime}$ neighboring deoxyguanosines

Among all known DNA intrastrand cross-links, the G(8-5m)T cross-link (Fig. S1 in the ESI $\dagger$ ) resulting from the ${ }^{\circ} \mathrm{U}_{\mathrm{CH}_{2}}$ radical attacking the $\mathrm{C}_{8}$ site of its $5^{\prime}$ neighboring deoxyguanosine is determined to have the highest yield. As depicted in Fig. 1, addition of the ${ }^{\prime} \mathrm{U}_{\mathrm{CH}_{2}}$ radical to the $\mathrm{C}_{8}$ site of its $5^{\prime}$ neighboring $\mathrm{dG}$ is unsurprisingly a one-step reaction. The distance (denoted as $d_{\mathrm{G} / \mathrm{C} 8-\mathrm{T} / \mathrm{C} 7}$ ) between the radical center (the $\mathrm{C}_{7}$ atom, related spin density distributions are shown in Fig. $\mathrm{S} 2$ and $\mathrm{S} 5$ in the ESI $\dagger$ ) of the ${ }^{-} \mathrm{U}_{\mathrm{CH}_{2}}$ radical and the $\mathrm{C}_{8}$ site of $\mathrm{dG}$ is decreased to $2.09 \AA$ in the located transition state (denoted as $\mathrm{TS}_{\mathrm{GU}}$ ) from a value of $3.60 \AA$ in the canonical $5^{\prime}-\mathrm{G}\left({ }^{\cdot} \mathrm{U}_{\mathrm{CH}_{2}}\right)-3^{\prime}$ sequence, and eventually reduced to $1.55 \AA$ forming a standard $\mathrm{C}-\mathrm{C}$ single bond in the addition product (denoted as $\left.5^{\prime}-\mathrm{G}_{8 \mathrm{H}}(8-5 \mathrm{~m}) \mathrm{T}-3^{\prime}\right)$. Meanwhile, evolution of the ${ }^{\cdot} \mathrm{U}_{\mathrm{CH}_{2}} / \mathrm{C}_{7}$ and $\mathrm{G} / \mathrm{C}_{8}$ atom hybridizations from $\mathrm{sp}^{2}$ to $\mathrm{sp}^{3}$ makes the $\mathrm{C}_{7}-\mathrm{C}_{5}$ bond in the $3^{\prime}{ }^{\prime} \mathrm{U}_{\mathrm{CH}_{2}}$ moiety and the $\mathrm{C}_{8}-\mathrm{N}_{7}$ and $\mathrm{C}_{8}-\mathrm{N}_{9}$ bonds in the $5^{\prime}$ dG moiety gradually elongated to $1.50,1.45$, and $1.48 \AA$ from $1.39,1.31$, and $1.38 \AA$, respectively, with the other bond length changes no more than $0.04 \AA$. Notably, along the reaction path, the torsion angle $\chi_{5^{\prime} \mathrm{G}}\left(\angle \mathrm{O}_{4^{\prime}} \mathrm{C}_{1^{\prime}} \mathrm{N}_{9} \mathrm{C}_{4}\right)$ continuously increases to $-77^{\circ}$ from $-130^{\circ}$ while the torsion angle $\chi_{3^{\prime} \mathrm{U}}\left(\angle \mathrm{O}_{4^{\prime}} \mathrm{C}_{1^{\prime}} \mathrm{N}_{1} \mathrm{C}_{2}\right)$ continuously decreases to $-126^{\circ}$ from $-101^{\circ}$, but the nucleobase moieties of both $3^{\prime} \cdot \mathrm{U}_{\mathrm{CH}_{2}}$ and $5^{\prime} \mathrm{dG}$ always maintain the anti-orientations, with the angle $\phi$ (defined as the dihedral angle between the planes of the two base moieties in a dinucleoside monophosphate) ranged from $4^{\circ}$ to $51^{\circ}$, which are well consistent with the simulation results reported previously. ${ }^{47}$

As listed in Table 1, an activation free energy of $17.27 \mathrm{kcal} \mathrm{mol}^{-1}$ is calculated, indicating that addition of the ${ }^{\cdot} \mathrm{U}_{\mathrm{CH}_{2}}$ radical to the $\mathrm{C}_{8}$ site of its $5^{\prime}$ neighboring deoxyguanosine is kinetically feasible. The current free energy barrier is 6$9 \mathrm{kcal} \mathrm{mol}^{-1}$ higher than those reported in the QM/MM simulation studies of an explicitly solvated $5^{\prime}-\mathrm{G}\left({ }^{\circ} \mathrm{U}_{\mathrm{CH}_{2}}\right)-3^{\prime}$ sequence and a solvated dodecameric sequence, ${ }^{41,46,47}$ which may be attributed to the inherent defect of the BLYP functional, namely always underestimating the transition state barriers by several kilocalories per mole. ${ }^{55}$ A reaction free energy of $1.41 \mathrm{kcal} \mathrm{mol}^{-1}$ is obtained for the $5^{\prime} \mathrm{G} / \mathrm{C}_{8}$ addition of the ${ }^{\cdot} \mathrm{U}_{\mathrm{CH}_{2}}$ radical,
Table 1 Related kinetic $\left(\Delta G^{*}\right)$ and thermodynamic $\left(\Delta G_{1}, \Delta G_{2}, \Delta G_{T}\right)$ characteristics for reactions of the ${ }^{\prime} \mathrm{U}_{\mathrm{CH}_{2}} \cdot \mathrm{T}_{6 \mathrm{OH}}$, and ${ }^{\circ} \mathrm{C}_{6 \mathrm{OH}}$ radicals adding to the $\mathrm{C}_{8}$ site of their $3^{\prime}$ and $5^{\prime}$ neighboring deoxyguanosines, respectively. Energies are in $\mathrm{kcal} \mathrm{mol}^{-1}$

\begin{tabular}{|c|c|c|c|c|}
\hline System & $\Delta G_{1}{ }^{a}$ & $\Delta G^{*}$ & $\Delta G_{2}{ }^{d}$ & $\Delta G_{\mathrm{T}}^{e}$ \\
\hline $5^{\prime}-\mathrm{G}\left({ }^{\circ} \mathrm{U}_{\mathrm{CH}_{2}}\right)-3^{\prime}$ & - & $17.27^{b}$ & 1.41 & 1.41 \\
\hline $5^{\prime}-\mathrm{G}\left({ }^{\circ} \mathrm{T}_{6 \mathrm{OH}}\right)-3^{\prime}$ & - & $17.45^{b}$ & 5.81 & 5.81 \\
\hline $5^{\prime}-\mathrm{G}\left({ }^{\circ} \mathrm{C}_{6 \mathrm{OH}}\right)-3^{\prime}$ & - & $15.25^{b}$ & 0.54 & 0.54 \\
\hline $5^{\prime}-\left(\cdot \mathrm{U}_{\mathrm{CH}_{2}}\right) \mathrm{G}-3^{\prime}$ & 9.12 & $17.37^{c}$ & 2.48 & 11.60 \\
\hline $5^{\prime}-\left({ }^{\circ} \mathrm{T}_{6 \mathrm{OH}}\right) \mathrm{G}-3^{\prime}$ & 18.23 & $14.74^{c}$ & 2.40 & 20.63 \\
\hline $5^{\prime}-\left(\cdot{ }^{-} \mathrm{C}_{6 \mathrm{OH}}\right) \mathrm{G}-3^{\prime}$ & 17.06 & $10.79^{c}$ & -5.13 & 11.94 \\
\hline
\end{tabular}

separately comparable to and ca. $5 \mathrm{kcal} \mathrm{mol}^{-1}$ lower than those reported in the above-mentioned two simulation studies. ${ }^{\mathbf{4 1 , 4 6 , 4 7}} \mathrm{A}$ positive reaction free energy here does not mean that the corresponding reaction step cannot occur. The ${ }^{\circ} \mathrm{U}_{\mathrm{CH}_{2}}$ radical addition step is actually coupled with the preceding step of formation of the ${ }^{\cdot} \mathrm{U}_{\mathrm{CH}_{2}}$ radical and the subsequent step of formation of the closed-shell $\mathrm{G}(8-5 \mathrm{~m}) \mathrm{T}$ intrastrand crosslink. ${ }^{41,45-47}$ As shown in Fig. S8 in the ESI, $\dagger 28.07 \mathrm{kcal} \mathrm{mol}^{-1}$ reaction free energy is released for the preceding step of formation of the canonical $5^{\prime}-\mathrm{G}\left({ }^{\cdot} \mathrm{U}_{\mathrm{CH}_{2}}\right)-3^{\prime}$ sequence, which makes the driving force for formation of the radical adduct $5^{\prime}$ ${ }^{-} \mathrm{G}_{8 \mathrm{H}}(8-5 \mathrm{~m}) \mathrm{T}-3^{\prime}$ estimated from the canonical 5'-GT-3' sequence much negative $\left(-26.66 \mathrm{kcal} \mathrm{mol}^{-1}\right)$. Moreover, the subsequent step of transformation of the radical adduct $5^{\prime}-{ }^{-} \mathrm{G}_{8 \mathrm{H}}(8-5 \mathrm{~m}) \mathrm{T}-3^{\prime}$ into the closed-shell $5^{\prime}-\mathrm{G}(8-5 \mathrm{~m}) \mathrm{T}-3^{\prime}$ cross-link further releases $81.67 \mathrm{kcal} \mathrm{mol}^{-1}$ reaction free energy (Fig. S9 in the ESI $\dagger$ ). Thus, besides involving only minor structural changes, the $5^{\prime} \mathrm{G} / \mathrm{C}_{8}$ addition of the ${ }^{\cdot} \mathrm{U}_{\mathrm{CH}_{2}}$ radical is also kinetically and thermodynamically feasible.

The ${ }^{\cdot} \mathrm{T}_{6 \mathrm{OH}}$ radical, which is produced three times more frequently than the ${ }^{\cdot} \mathrm{U}_{\mathrm{CH}_{2}}$ radical, ${ }^{36}$ is shown to be able to attack the $\mathrm{C}_{8}$ site of its $3^{\prime} / 5^{\prime}$ neighboring deoxyguanosine forming the $\mathrm{G}(8-5) \mathrm{T}_{6 \mathrm{OH}}$ or $\mathrm{T}_{6 \mathrm{OH}}(5-8) \mathrm{G}$ intrastrand cross-link (Fig. $\mathrm{S} 1$ in the $\mathrm{ESI} \dagger$ ), although the yields of both cross-links are much lower than those of the corresponding $\mathrm{G}(8-5 \mathrm{~m}) \mathrm{T}$ and $\mathrm{T}(5 \mathrm{~m}-8) \mathrm{G}$ cross-
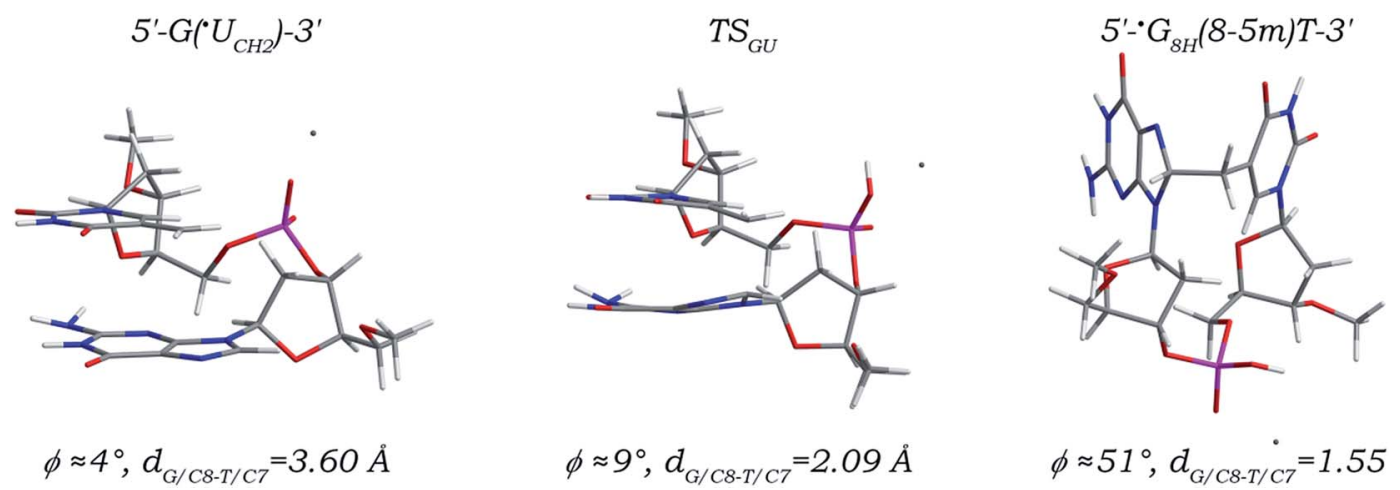

Fig. 1 Optimized structures and partial structural parameters for stationary points along the reaction path of the ${ }^{\circ} \mathrm{U}_{\mathrm{CH}_{2}}$ radical addition to the $\mathrm{C}_{8}$ site of its $5^{\prime}$ neighboring deoxyguanosine. 
links, respectively. ${ }^{12,13,15,23,56}$ A complete reaction path of the ${ }^{\prime} \mathrm{T}_{6 \mathrm{OH}}$ radical addition to the $\mathrm{C}_{8}$ site of its $5^{\prime}$ neighboring deoxyguanosine is depicted in Fig. 2, and related kinetic and thermodynamic characteristics are listed in Table 1 . The $5^{\prime} \mathrm{G} / \mathrm{C}_{8}$ addition of the ${ }^{\circ} \mathrm{T}_{6 \mathrm{OH}}$ radical is also a one-step reaction. In the located transition state (denoted as $\mathrm{TS}_{\mathrm{GT}}$ ), the distance (denoted as $d_{\mathrm{G} / \mathrm{C} 8-\mathrm{T} / \mathrm{C} 5}$ ) between the radical center (the $\mathrm{C}_{5}$ atom, related spin density distributions are shown in Fig. S3 and S6 in the ESI $\dagger$ ) of the ${ }^{~} \mathrm{~T}_{6 \mathrm{OH}}$ radical and the $\mathrm{C}_{8}$ site of $\mathrm{dG}$ is reduced to $2.13 \AA$ from $3.38 \AA$ in the canonical $5^{\prime}-\mathrm{G}\left({ }^{\circ} \mathrm{T}_{6 \mathrm{OH}}\right)-3^{\prime}$ sequence, and finally decreased to $1.60 \AA$ forming a $\mathrm{C}-\mathrm{C}$ single bond in the addition product (denoted as $\left.5^{\prime}-\mathrm{G}_{8 \mathrm{H}}(8-5) \mathrm{T}_{6 \mathrm{OH}^{-}} 3^{\prime}\right)$. All bond length changes are found to be no more than $0.04 \AA$ except that the $\mathrm{C}_{8}-\mathrm{N}_{7}$ and $\mathrm{C}_{8}-\mathrm{N}_{9}$ bonds in the $5^{\prime} \mathrm{dG}$ moiety and the $\mathrm{C}_{5}-\mathrm{C}_{4}$, $\mathrm{C}_{5}-\mathrm{C}_{6}$, and $\mathrm{C}_{5}-\mathrm{C}_{7}$ bonds in the $3^{\prime}{ }^{\circ} \mathrm{T}_{6 \mathrm{OH}}$ moiety are separately elongated to $1.46,1.47,1.53,1.54$, and $1.53 \AA$ from values of $1.31,1.38,1.45,1.49$, and $1.48 \AA$ due to hybridization transitions of the $\mathrm{G} / \mathrm{C}_{8}$ and ${ }^{\top} \mathrm{T}_{6 \mathrm{OH}} / \mathrm{C}_{5}$ atoms from $\mathrm{sp}^{2}$ to $\mathrm{sp}^{3}$. The antiorientations of both nucleobase moieties are always maintained along the reaction path, with the two torsion angles $\chi_{5^{\prime} \mathrm{G}}$ $\left(\angle \mathrm{O}_{4^{\prime}} \mathrm{C}_{1^{\prime}} \mathrm{N}_{9} \mathrm{C}_{4}\right)$ and $\chi_{3^{\prime} \mathrm{T}}\left(\angle \mathrm{O}_{4^{\prime}} \mathrm{C}_{1^{\prime}} \mathrm{N}_{1} \mathrm{C}_{2}\right)$ merely continuously increased to $-80^{\circ}$ and $-119^{\circ}$ from $-111^{\circ}$ and $-146^{\circ}$, respectively. Thus, just like the $5^{\prime} \mathrm{G} / \mathrm{C}_{8}$ addition of the ${ }^{\cdot} \mathrm{U}_{\mathrm{CH}_{2}}$, radical, addition of the ${ }^{~} \mathrm{~T}_{6 \mathrm{OH}}$ radical to the $\mathrm{C}_{8}$ site of its $5^{\prime}$ neighboring deoxyguanosine also gives rise to only small effects on the local DNA structure.

As listed in Table 1, the activation free energy for the $5^{\prime} \mathrm{G} / \mathrm{C}_{8}$ addition of the ${ }^{\prime} \mathrm{T}_{6 \mathrm{OH}}$ radical is calculated to be $17.45 \mathrm{kcal} \mathrm{mol}^{-1}$, kinetically comparable to that needed for the $5^{\prime} \mathrm{G} / \mathrm{C}_{8}$ addition of the ${ }^{-} \mathrm{U}_{\mathrm{CH}_{2}}$ radical. Starting from the canonical $5^{\prime}-\mathrm{G}\left({ }^{\cdot} \mathrm{T}_{6 \mathrm{OH}}\right)-3^{\prime}$ sequence, the reaction free energy for formation of the $5^{\prime}-\mathrm{G}_{8 \mathrm{H}}(8-5) \mathrm{T}_{6 \mathrm{OH}^{-}} 3^{\prime}$ adduct is estimated to be $5.81 \mathrm{kcal} \mathrm{mol}^{-1}, 4.4 \mathrm{kcal} \mathrm{mol}^{-1}$ larger than that for formation of the $5^{\prime}-{ }^{-} \mathrm{G}_{8 \mathrm{H}}(8-5 \mathrm{~m}) \mathrm{T}-3^{\prime}$ adduct. The $5^{\prime} \mathrm{G} / \mathrm{C}_{8}$ addition of the ${ }^{\circ} \mathrm{T}_{6 \mathrm{OH}}$ radical is thus thermodynamically less efficient than the $5^{\prime} \mathrm{G} / \mathrm{C}_{8}$ addition of the ${ }^{\circ} \mathrm{U}_{\mathrm{CH}_{2}}$ radical, providing a plausible explanation for the experimental observation that the yield of the $\mathrm{G}(8-5) \mathrm{T}_{6 \mathrm{OH}}$ cross-link is much lower than that of the $\mathrm{G}(8-5 \mathrm{~m}) \mathrm{T}$ cross-link. The driving force for formation of the $5^{\prime}-\mathrm{G}_{8 \mathrm{H}}(8-5) \mathrm{T}_{6 \mathrm{OH}^{-}} 3^{\prime}$ adduct is reduced to $c a$. $-16 \mathrm{kcal} \mathrm{mol}^{-1}$ when taking into account the preceding step of formation of the canonical $5^{\prime}$ -
$\mathrm{G}\left({ }^{\circ} \mathrm{T}_{6 \mathrm{OH}}\right)-3^{\prime}$ sequence (Fig. S8 in the ESI, $\dagger-21.83 \mathrm{kcal} \mathrm{mol}^{-1}$ reaction free energy is calculated). Furthermore, $81.33 \mathrm{kcal} \mathrm{mol}^{-1}$ reaction free energy is released for subsequent transformation of the radical adduct $5^{\prime}-\mathrm{G}_{8 \mathrm{H}}(8-5) \mathrm{T}_{6 \mathrm{OH}^{-}} 3^{\prime}$ into the $5^{\prime}-\mathrm{G}(8-5) \mathrm{T}_{6 \mathrm{OH}^{-3}}{ }^{\prime}$ cross-link (Fig. S9 in the ESI $\dagger$ ). Therefore, as in the case of the $5^{\prime} \mathrm{G} / \mathrm{C}_{8}$ addition of the ${ }^{\cdot} \mathrm{U}_{\mathrm{CH}_{2}}$ radical, the $5^{\prime} \mathrm{G} / \mathrm{C}_{8}$ addition of the ${ }^{1} \mathrm{~T}_{6 \mathrm{OH}}$ radical is also thermodynamically feasible.

G(8-5)C and C(5-8)G intrastrand cross-links (Fig. S1 in the ESI $\dagger$ ) have been definitely detected in DNA oligomer, duplex DNA, and mammalian cells irradiated by $\gamma$-/X-ray ${ }^{13,16,19,23}$ or treated with Fenton-type reagents. ${ }^{20}$ Formation of both intrastrand cross-links is believed to be a single-radical event, and be associated with the ${ }^{\circ} \mathrm{C}_{6 \mathrm{OH}}$ radical. ${ }^{13}$ Reaction path of the ${ }^{\circ} \mathrm{C}_{6 \mathrm{OH}}$ radical addition to the $\mathrm{C}_{8}$ site of its $5^{\prime}$ neighboring deoxyguanosine and related kinetic and thermodynamic characteristics are shown in Fig. 3 and Table 1, respectively. Obviously, as in the cases of the $5^{\prime} \mathrm{G} / \mathrm{C}_{8}$ additions of the ${ }^{\circ} \mathrm{U}_{\mathrm{CH}_{2}}$ and ${ }^{\prime} \mathrm{T}_{6 \mathrm{OH}}$ radicals, the $5^{\prime} \mathrm{G} / \mathrm{C}_{8}$ addition of the ${ }^{\circ} \mathrm{C}_{6 \mathrm{OH}}$ radical is also a simple direct one-step reaction. The distance (denoted as $d_{\mathrm{G} / \mathrm{C} 8 \mathrm{-C} / \mathrm{C} 5}$ ) between the radical center (the $\mathrm{C}_{5}$ atom, related spin density distributions are shown in Fig. S4 and S7 in the ESI $\dagger$ ) of the ${ }^{\circ} \mathrm{C}_{6 \mathrm{OH}}$ radical and the $\mathrm{C}_{8}$ site of $\mathrm{dG}$ is lowered to $2.15 \AA$ in the located transition state (denoted as $\mathrm{TS}_{\mathrm{GC}}$ ) from $3.41 \AA$ in the canonical $5^{\prime}-\mathrm{G}\left({ }^{\circ} \mathrm{C}_{6 \mathrm{OH}}\right)-3^{\prime}$ sequence, and ultimately reduced to $1.57 \AA$ forming a standard $\mathrm{C}-\mathrm{C}$ single bond in the addition product (denoted as $\left.5^{\prime}-\mathrm{G}_{8 \mathrm{H}}(8-5) \mathrm{C}_{6 \mathrm{OH}^{-}}-3^{\prime}\right)$. Meanwhile, the $\mathrm{C}_{8}-\mathrm{N}_{7}$ and $\mathrm{C}_{8}-\mathrm{N}_{9}$ bonds in the $5^{\prime} \mathrm{dG}$ moiety and the $\mathrm{C}_{5}-\mathrm{C}_{4}$ and $\mathrm{C}_{5}-\mathrm{C}_{6}$ bonds in the $3^{\prime}{ }^{\prime} \mathrm{C}_{6 \mathrm{OH}}$ moiety are separately stretched to 1.45 , $1.47,1.51$, and $1.53 \AA$ from values of $1.31,1.38,1.44$, and $1.49 \AA$ due to hybridization transitions of the $\mathrm{G} / \mathrm{C}_{8}$ and ${ }^{\circ} \mathrm{C}_{6 \mathrm{OH}} / \mathrm{C}_{5}$ atoms from $\mathrm{sp}^{2}$ to $\mathrm{sp}^{3}$, with the other bond length changes no more than $0.04 \AA$. Once again, the anti-orientations of both nucleobase moieties are maintained along the reaction path with the angle $\phi$ increased from $18^{\circ}$ to $35^{\circ}$, implying that formation of the $5^{\prime}-\mathrm{G}_{8 \mathrm{H}}(8-5) \mathrm{C}_{6 \mathrm{OH}^{-}} 3^{\prime}$ adduct has only relatively small influences on the local DNA structure. Addition of the ${ }^{\circ} \mathrm{C}_{6 \mathrm{OH}}$ radical to the $\mathrm{C}_{8}$ site of its $5^{\prime}$ neighboring deoxyguanosine is kinetically feasible, with $15.25 \mathrm{kcal} \mathrm{mol}^{-1}$ activation free energy being calculated (Table 1). On the other hand, the reaction free energy is estimated to be $0.54 \mathrm{kcal} \mathrm{mol}^{-1}$, indicating that the $5^{\prime} \mathrm{G} / \mathrm{C}_{8}$
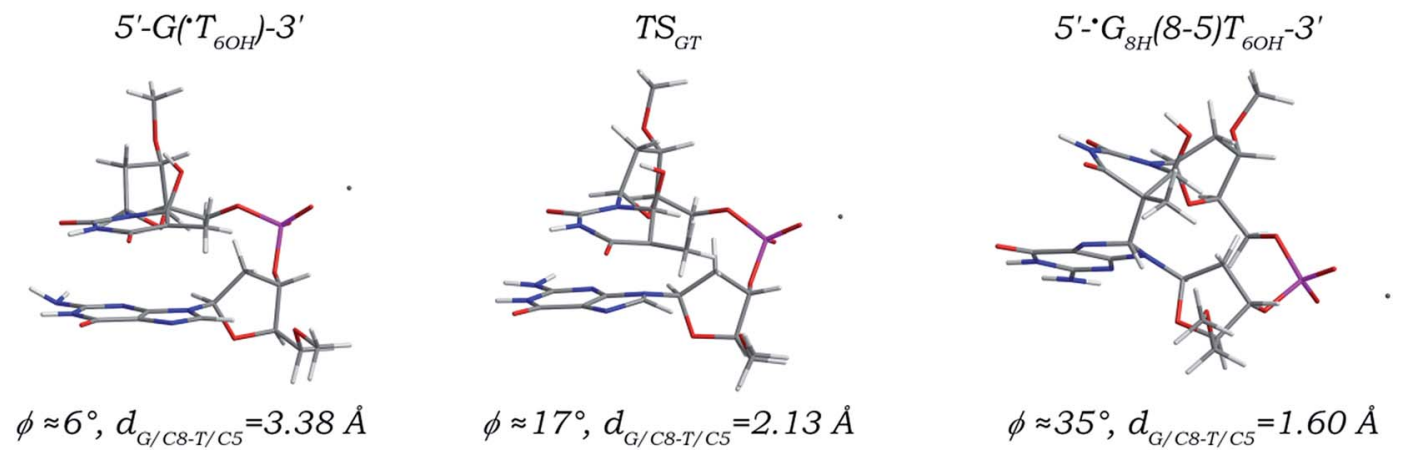

Fig. 2 Optimized structures and partial structural parameters for stationary points along the reaction path of the ${ }^{\circ} T_{6 \mathrm{OH}}$ radical addition to the $\mathrm{C}_{8}$ site of its $5^{\prime}$ neighboring deoxyguanosine. 


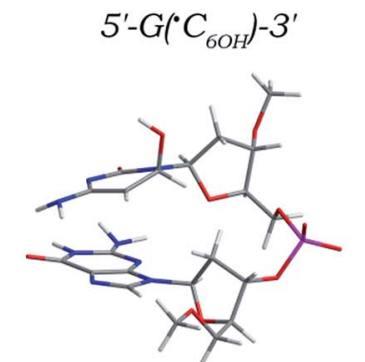

$$
\phi \approx 18^{\circ}, d_{G / C 8-C / C 5}=3.41 \AA
$$
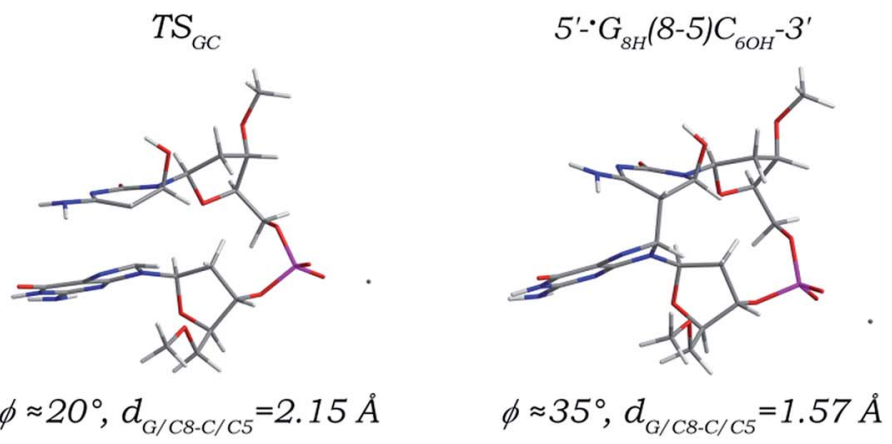

Fig. 3 Optimized structures and partial structural parameters for stationary points along the reaction path of the ${ }^{\circ} \mathrm{C}_{6 \mathrm{OH}}$ radical addition to the $\mathrm{C}_{8}$ site of its $5^{\prime}$ neighboring deoxyguanosine.

addition step of the ${ }^{\circ} \mathrm{C}_{6 \mathrm{OH}}$ radical is thermodynamically slightly unfavourable. But as shown in Fig. S8 and S9 in the ESI, $\uparrow$ the preceding step of formation of the canonical $5^{\prime}-\mathrm{G}\left({ }^{\circ} \mathrm{C}_{6 \mathrm{OH}}\right)-3^{\prime}$ sequence and the subsequent step of formation of the closedshell $5^{\prime}-\mathrm{G}(8-5) \mathrm{C}-3^{\prime}$ cross-link are both thermodynamically favourable. Hence, when coupled with these reaction steps, the ${ }^{\circ} \mathrm{C}_{6 \mathrm{OH}}$ radical addition to the $\mathrm{C}_{8}$ site of its $5^{\prime}$ neighboring deoxyguanosine forming the $5^{\prime}-\mathrm{G}_{8 \mathrm{H}}(8-5) \mathrm{C}_{6 \mathrm{OH}^{-}} 3^{\prime}$ adduct is thermodynamically feasible.

In short, additions of the ${ }^{\circ} \mathrm{U}_{\mathrm{CH}_{2}}, \mathrm{~T}_{6 \mathrm{OH}}$, and ${ }^{\circ} \mathrm{C}_{6 \mathrm{OH}}$ radicals to the $\mathrm{C}_{8}$ site of their $5^{\prime}$ neighboring deoxyguanosines are all simple direct one-step reactions, imposing only minor influences on the local DNA structure. On the other hand, all these three addition reactions are kinetically and thermodynamically feasible, and the more unfavourable thermodynamic requirement for the $5^{\prime} \mathrm{G} / \mathrm{C}_{8}$ addition of the ${ }^{~} \mathrm{~T}_{6 \mathrm{OH}}$ radical than that for the $5^{\prime} \mathrm{G} / \mathrm{C}_{8}$ addition of the ${ }^{\circ} \mathrm{U}_{\mathrm{CH}_{2}}$ radical may be the reasons leading to the fact that the yield of the $\mathrm{G}(8-5) \mathrm{T}_{6 \mathrm{OH}}$ intrastrand cross-link is much lower than that of the $\mathrm{G}(8-5 \mathrm{~m}) \mathrm{T}$ intrastrand cross-link.

\section{Additions of the ${ }^{\circ} \mathrm{U}_{\mathrm{CH}_{2}},{ }^{\circ} \mathrm{T}_{6 \mathrm{OH}}$, and ${ }^{\circ} \mathrm{C}_{6 \mathrm{OH}}$ radicals to the $\mathrm{C}_{8}$ site of their $3^{\prime}$ neighboring deoxyguanosines}

Different from the simple one-step $5^{\prime} \mathrm{G} / \mathrm{C}_{8}$ addition, as depicted in Fig. 4 , the reaction path of the ${ }^{\circ} \mathrm{U}_{\mathrm{CH}_{2}}$ radical addition to the $\mathrm{C}_{8}$ site of its $3^{\prime}$ neighboring deoxyguanosine is rather complex. Before the $3^{\prime} \mathrm{G} / \mathrm{C}_{8}$ addition step proceeds, a large structural adjustment from the initial canonical $5^{\prime}-\left({ }^{\cdot} \mathrm{U}_{\mathrm{CH}_{2}}\right) \mathrm{G}-3^{\prime}$ sequence to an intermediate (denoted as $\mathrm{INT}_{\mathrm{UG}}$ ) is firstly required. The torsion angles $\chi_{5^{\prime} \mathrm{U}}\left(\angle \mathrm{O}_{4^{\prime}} \mathrm{C}_{1^{\prime}} \mathrm{N}_{1} \mathrm{C}_{2}\right)$ and $\chi_{3^{\prime} \mathrm{G}}\left(\angle \mathrm{O}_{4^{\prime}} \mathrm{C}_{1^{\prime}} \mathrm{N}_{9} \mathrm{C}_{4}\right)$ are increased to $25^{\circ}$ and $-39^{\circ}$ from values of $-107^{\circ}$ and $-87^{\circ}$ (Table 2), eventually making the nucleobase moieties of $5^{\prime}{ }^{\circ} \mathrm{U}_{\mathrm{CH}_{2}}$ and $3^{\prime}$ dG adopt a syn-orientation and a near T-shaped orientation, respectively. Meanwhile, the DNA backbone rotates primarily around the $\mathrm{C}_{3^{\prime}}-\mathrm{O}_{3^{\prime}}, \mathrm{O}_{3^{\prime}}-\mathrm{P}$, and $\mathrm{P}-\mathrm{O}_{5^{\prime}}$ bonds, with the torsion angles $\alpha\left(\angle \mathrm{C}_{4^{\prime}} \mathrm{C}_{3^{\prime}} \mathrm{O}_{3^{\prime}} \mathrm{P}\right), \beta\left(\angle \mathrm{C}_{3^{\prime}} \mathrm{O}_{3^{\prime}} \mathrm{PO}_{5^{\prime}}\right)$, and $\gamma\left(\angle \mathrm{O}_{3^{\prime}} \mathrm{PO}_{5^{\prime}} \mathrm{C}_{5^{\prime}}\right)$ changed from $179^{\circ},-112^{\circ}$, and $-62^{\circ}$ to $155^{\circ},-86^{\circ}$, and $-80^{\circ}$, respectively. Rotation of both nucleobase moieties about their corresponding glycosidic bonds and twist of the DNA backbone collectively lead to the two nucleobase moieties parallel with the angle $\phi$ being $4^{\circ}$ in the intermediate $\mathrm{INT}_{\mathrm{UG}}$, and further the distance $d_{\mathrm{G} / \mathrm{C} 8-\mathrm{T} / \mathrm{C} 7}$ is obviously decreased from $7.01 \AA$ to $3.38 \AA$. Starting from the $\mathrm{INT}_{\mathrm{UG}}$ intermediate, the $3^{\prime} \mathrm{G} / \mathrm{C}_{8}$ addition step proceeds (Fig. 4). The distance $d_{\mathrm{G} / \mathrm{C} 8-\mathrm{T} / \mathrm{C} 7}$ is lowered to $2.11 \AA$ in the located transition state (denoted as $\mathrm{TS}_{\mathrm{UG}}$ ), and ultimately reduced to $1.57 \AA$ forming a standard $\mathrm{C}-\mathrm{C}$ single bond in the addition product (denoted as $\left.5^{\prime}-\mathrm{T}(5 \mathrm{~m}-8)\left({ }^{\cdot} \mathrm{G}_{8 \mathrm{H}}\right)-3^{\prime}\right)$. Hybridization transitions of both ${ }^{\circ} \mathrm{U}_{\mathrm{CH}_{2}} / \mathrm{C}_{7}$ and $\mathrm{G} / \mathrm{C}_{8}$ atoms from $\mathrm{sp}^{2}$ to $\mathrm{sp}^{3}$ make the bond length changes of the related $\mathrm{C}_{7}-\mathrm{C}_{5}$ bond in the $5^{\prime} \cdot \mathrm{U}_{\mathrm{CH}_{2}}$ moiety and the $\mathrm{C}_{8}-\mathrm{N}_{7}$ and $\mathrm{C}_{8}-\mathrm{N}_{9}$ bonds in the $3^{\prime} \mathrm{dG}$ moiety nearly the same as those observed in the case of the $5^{\prime} \mathrm{G} /$ $\mathrm{C}_{8}$ addition, and the other bonds are relatively stable with their bond length changes no more than $0.04 \AA$. Along the $3^{\prime} \mathrm{G} / \mathrm{C}_{8}$ addition path, the angle $\phi$ only fluctuates within the range of 4-

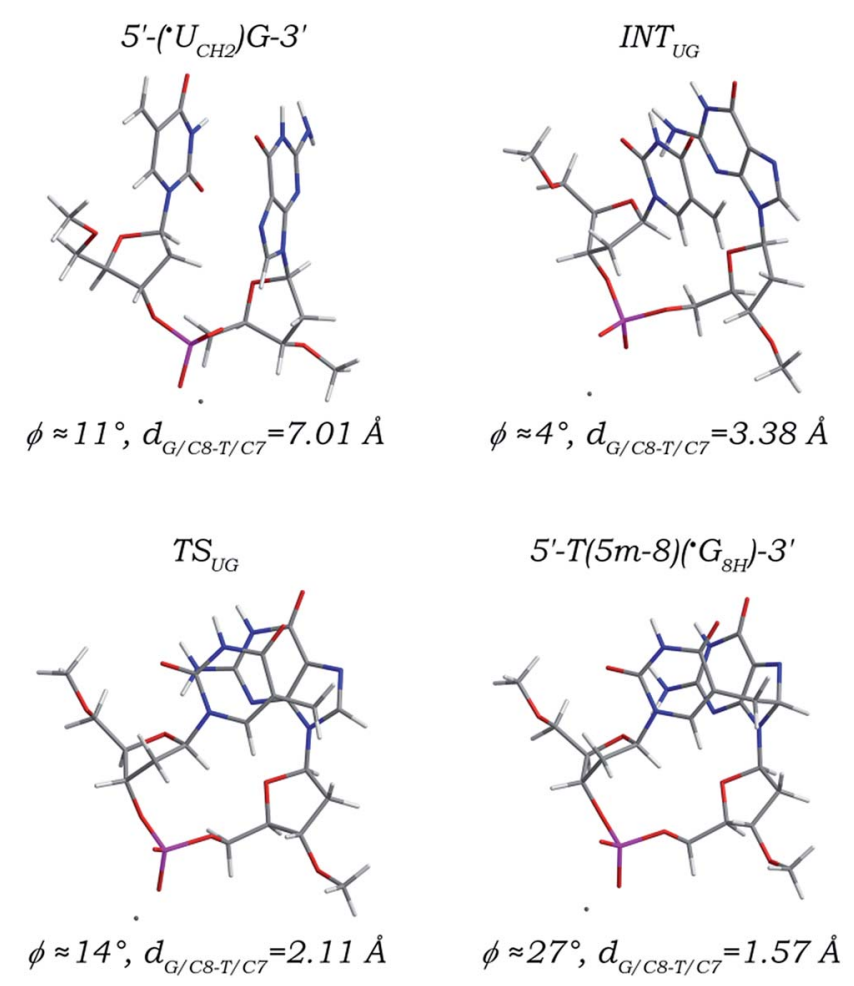

Fig. 4 Optimized structures and partial structural parameters for stationary points along the reaction path of the $\mathrm{U}_{\mathrm{CH}_{2}}$ radical addition to the $\mathrm{C}_{8}$ site of its $3^{\prime}$ neighboring deoxyguanosine. 
Table 2 Alterations of the dihedral angles $\chi_{5^{\prime}}\left(\angle \mathrm{O}_{4^{\prime}} \mathrm{C}_{1^{\prime}} \mathrm{N}_{1} \mathrm{C}_{2}\right), \chi_{3^{\prime}}$ $\left(\angle \mathrm{O}_{4^{\prime}} \mathrm{C}_{1^{\prime}} \mathrm{N}_{9} \mathrm{C}_{4}\right), \alpha\left(\angle \mathrm{C}_{4^{\prime}} \mathrm{C}_{3^{\prime}} \mathrm{O}_{3^{\prime}} \mathrm{P}\right), \beta\left(\angle \mathrm{C}_{3^{\prime}} \mathrm{O}_{3^{\prime}} \mathrm{PO}_{5^{\prime}}\right), \gamma\left(\angle \mathrm{O}_{3^{\prime}} \mathrm{PO}_{5^{\prime}} \mathrm{C}_{5^{\prime}}\right)$, and $\delta\left(\angle \mathrm{PO}_{5^{\prime}}, \mathrm{C}_{5^{\prime}} \mathrm{C}_{4^{\prime}}\right)$ involved in the essential conformational adjustments along the $3^{\prime} \mathrm{G} / \mathrm{C}_{8}$ additions of the ${ }^{\circ} \mathrm{U}_{\mathrm{CH}_{2}}{ }^{\cdot} \mathrm{T}_{6 \mathrm{OH}}$, and ${ }^{\circ} \mathrm{C}_{6 \mathrm{OH}}$ radicals, respectively

\begin{tabular}{lllllll}
\hline Structure & $\chi_{5^{\prime}}$ & $\chi_{3^{\prime}}$ & $\alpha$ & $\beta$ & $\gamma$ & $\delta$ \\
\hline $5^{\prime}-\left({ }^{\circ} \mathrm{U}_{\mathrm{CH}_{2}}\right) \mathrm{G}-3^{\prime}$ & $-107^{\circ}$ & $-87^{\circ}$ & $179^{\circ}$ & $-112^{\circ}$ & $-62^{\circ}$ & $-175^{\circ}$ \\
$\mathrm{INT}_{\mathrm{UG}}$ & $25^{\circ}$ & $-39^{\circ}$ & $155^{\circ}$ & $-86^{\circ}$ & $-80^{\circ}$ & $173^{\circ}$ \\
$5^{\prime}-\left({ }^{\circ} \mathrm{T}_{6 \mathrm{OH}}\right) \mathrm{G}-3^{\prime}$ & $-78^{\circ}$ & $-103^{\circ}$ & $161^{\circ}$ & $-103^{\circ}$ & $-56^{\circ}$ & $178^{\circ}$ \\
$\mathrm{INT}_{\mathrm{TG}}$ & $51^{\circ}$ & $-52^{\circ}$ & $144^{\circ}$ & $-95^{\circ}$ & $-80^{\circ}$ & $153^{\circ}$ \\
$5^{\prime}-\left({ }^{\circ} \mathrm{C}_{6 \mathrm{OH}}\right) \mathrm{G}-3^{\prime}$ & $-77^{\circ}$ & $-102^{\circ}$ & $162^{\circ}$ & $-101^{\circ}$ & $-57^{\circ}$ & $-179^{\circ}$ \\
$\mathrm{INT}_{\mathrm{CG}}$ & $54^{\circ}$ & $-48^{\circ}$ & $149^{\circ}$ & $-94^{\circ}$ & $-84^{\circ}$ & $150^{\circ}$ \\
& & & & & &
\end{tabular}

$27^{\circ}$, but the prerequisite requirement of a large conformational transformation from the initial canonical $5^{\prime}-\left({ }^{\cdot} \mathrm{U}_{\mathrm{CH}_{2}}\right) \mathrm{G}-3^{\prime}$ sequence to an intermediate $\mathrm{INT}_{\mathrm{UG}}$ implies that addition of the ${ }^{\prime} \mathrm{U}_{\mathrm{CH}_{2}}$ radical to the $\mathrm{C}_{8}$ site of its $3^{\prime}$ neighboring deoxyguanosine is obviously structurally disadvantageous, and may greatly influence the local DNA structure.

For the $3^{\prime} \mathrm{G} / \mathrm{C}_{8}$ addition step, an activation free energy of $17.37 \mathrm{kcal} \mathrm{mol}^{-1}$ (Table 1), which is nearly equal to that required in the $5^{\prime} \mathrm{G} / \mathrm{C}_{8}$ addition, and a reaction free energy of $2.48 \mathrm{kcal} \mathrm{mol}^{-1}$ are calculated. One point to be noted is that, besides structurally disadvantageous, the prerequisite conformational adjustment from the canonical $5^{\prime}-\left({ }^{\cdot} \mathrm{U}_{\mathrm{CH}_{2}}\right) \mathrm{G}-3^{\prime}$ sequence to the intermediate $\mathrm{INT}_{\mathrm{UG}}$ is also thermodynamically unfavourable, with $9.12 \mathrm{kcal} \mathrm{mol}^{-1}$ reaction free energy being absorbed. As a result, the reaction free energy for the $3^{\prime} \mathrm{G} / \mathrm{C}_{8}$ addition estimated from the canonical $5^{\prime}-\left({ }^{-} \mathrm{U}_{\mathrm{CH}_{2}}\right) \mathrm{G}-3^{\prime}$ sequence is increased to as positive as $11.60 \mathrm{kcal} \mathrm{mol}^{-1}, c a .10 \mathrm{kcal} \mathrm{mol}^{-1}$ higher than that for the simple $5^{\prime} \mathrm{G} / \mathrm{C}_{8}$ addition. Hence, from the thermodynamic point of view, addition of the ${ }^{\circ} \mathrm{U}_{\mathrm{CH}_{2}}$ radical to the $\mathrm{C}_{8}$ site of its $3^{\prime}$ neighboring deoxyguanosine forming the $5^{\prime}-\mathrm{T}(5 \mathrm{~m}-8)\left({ }^{\circ} \mathrm{G}_{8 \mathrm{H}}\right)-3^{\prime}$ adduct is much more inefficient than that to the $\mathrm{C}_{8}$ site of its $5^{\prime}$ neighboring deoxyguanosine forming the $5^{\prime}$ ${ }^{\cdot} \mathrm{G}_{8 \mathrm{H}}(8-5 \mathrm{~m}) \mathrm{T}-3^{\prime}$ adduct. However, the $11.60 \mathrm{kcal} \mathrm{mol}^{-1}$ reaction free energy does also not mean that the $3^{\prime} \mathrm{G} / \mathrm{C}_{8}$ addition of the $\cdot \mathrm{U}_{\mathrm{CH}_{2}}$ radical cannot occur. When coupled with the thermodynamically favourable preceding step of formation of the canonical $5^{\prime}-\left({ }^{\prime} \mathrm{U}_{\mathrm{CH}_{2}}\right) \mathrm{G}-3^{\prime}$ sequence and the subsequent step of formation of the closed-shell $5^{\prime}-\mathrm{T}(5 \mathrm{~m}-8) \mathrm{G}-3^{\prime}$ cross-link (Fig. S8 and S9 in the ESI, $\dagger-26.03$ and $-88.06 \mathrm{kcal} \mathrm{mol}^{-1}$ reaction free energies are separately estimated), addition of the ${ }^{\circ} \mathrm{U}_{\mathrm{CH}_{2}}$ radical to the $\mathrm{C}_{8}$ site of its $3^{\prime}$ neighboring deoxyguanosine is in fact thermodynamically feasible.

A reaction path (Fig. 5) much similar to that of the $3^{\prime} \mathrm{G} / \mathrm{C}_{8}$ addition of the ${ }^{\circ} \mathrm{U}_{\mathrm{CH}_{2}}$ radical is found for the ${ }^{\circ} \mathrm{T}_{6 \mathrm{OH}}$ radical addition to the $\mathrm{C}_{8}$ site of its $3^{\prime}$ neighboring deoxyguanosine. The initial canonical $5^{\prime}-\left({ }^{\circ} \mathrm{T}_{6 \mathrm{OH}}\right) \mathrm{G}-3^{\prime}$ sequence must be firstly transformed into an intermediate (denoted as $\mathrm{INT}_{\mathrm{TG}}$ ) before the $3^{\prime} \mathrm{G} /$ $\mathrm{C}_{8}$ addition step proceeds. As reflected by the changes of the related torsion angles listed in Table 2, the two nucleobase moieties are separately converted to syn- and T-shaped orientations from anti- and anti-orientations, and the DNA backbone twists around the $\mathrm{C}_{3^{\prime}}-\mathrm{O}_{3^{\prime}}, \mathrm{O}_{3^{\prime}}-\mathrm{P}, \mathrm{P}-\mathrm{O}_{5^{\prime}}$, and $\mathrm{C}_{5^{\prime}}-\mathrm{O}_{5^{\prime}}$ bonds. Synergy of orientation transitions of both nucleobase moieties
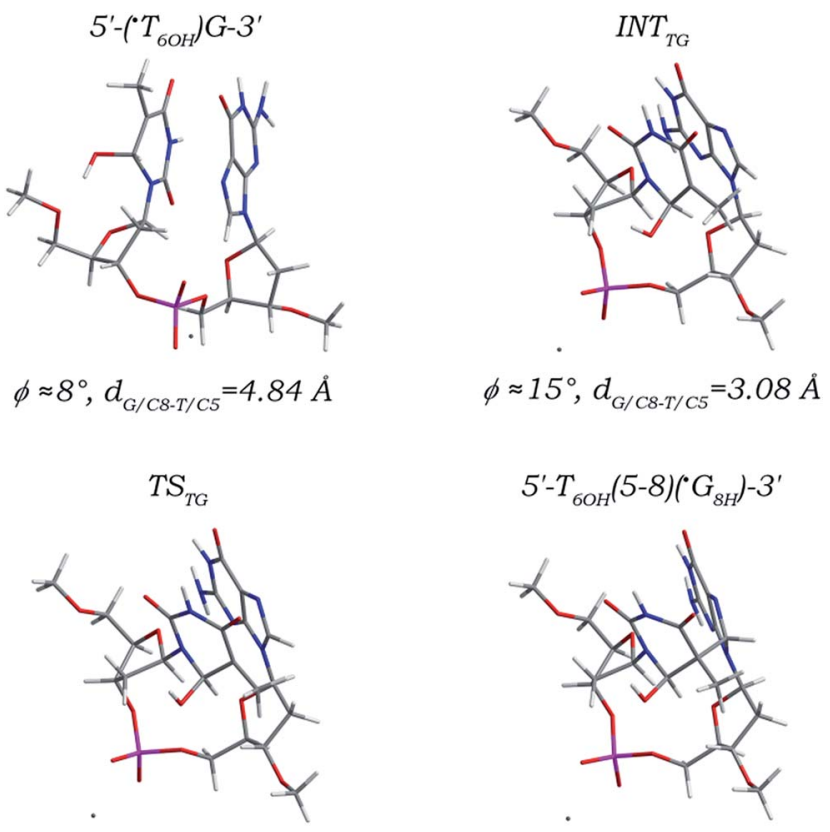

$\phi \approx 23^{\circ}, d_{G / C 8-T / C 5}=2.16 \AA$

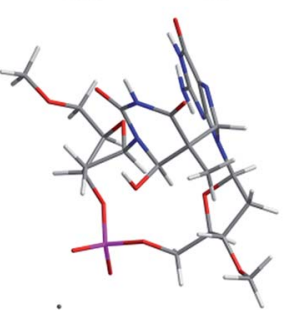

$\phi \approx 36^{\circ}, d_{G / C 8-T / C 5}=1.59 \AA$

Fig. 5 Optimized structures and partial structural parameters for stationary points along the reaction path of the ${ }^{\top} \mathrm{T}_{6 \mathrm{OH}}$ radical addition to the $\mathrm{C}_{8}$ site of its $3^{\prime}$ neighboring deoxyguanosine.

and twist of DNA backbone makes the distance $d_{\mathrm{G} / \mathrm{C} 8-\mathrm{T} / \mathrm{C} 5}$ lowered from $4.84 \AA$ in the canonical $5^{\prime}-\left({ }^{\circ} \mathrm{T}_{6 \mathrm{OH}}\right) \mathrm{G}-3^{\prime}$ sequence to $3.08 \AA$ in the $\mathrm{INT}_{\mathrm{TG}}$ intermediate, which is further reduced to $2.16 \AA$ in the located transition state (denoted as $\mathrm{TS}_{\mathrm{TG}}$ ) for the $3^{\prime} \mathrm{G} / \mathrm{C}_{8}$ addition step, and ultimately decreased to $1.59 \AA$ forming a C-C single bond in the addition product (denoted as $\left.5^{\prime}-\mathrm{T}_{6 \mathrm{OH}}(5-8)\left({ }^{\circ} \mathrm{G}_{8 \mathrm{H}}\right)-3^{\prime}\right)$. Since the ${ }^{\cdot} \mathrm{T}_{6 \mathrm{OH}} / \mathrm{C}_{5}$ and $\mathrm{G} / \mathrm{C}_{8}$ atom hybridizations are also changed from $\mathrm{sp}^{2}$ to $\mathrm{sp}^{3}$, bond length alterations of the $\mathrm{C}_{5}-\mathrm{C}_{4}$, $\mathrm{C}_{5}-\mathrm{C}_{6}$, and $\mathrm{C}_{5}-\mathrm{C}_{7}$ bonds in the $5^{\prime}{ }^{\circ} \mathrm{T}_{6 \mathrm{OH}}$ moiety and the $\mathrm{C}_{8}-\mathrm{N}_{7}$ and $\mathrm{C}_{8}-\mathrm{N}_{9}$ bonds in the $3^{\prime}$ dG moiety as well as the other bonds are shown to be nearly the same as those observed in the $5^{\prime} \mathrm{G} / \mathrm{C}_{8}$ addition of the ${ }^{\top} \mathrm{T}_{6 \mathrm{OH}}$ radical. Although the increment of the angle $\phi\left(28^{\circ}\right)$ along the $3^{\prime} \mathrm{G} / \mathrm{C}_{8}$ addition path is comparable to that $\left(29^{\circ}\right)$ along the $5^{\prime} \mathrm{G} / \mathrm{C}_{8}$ addition path, different from its sequence isomer $5^{\prime}-{ }^{-} \mathrm{G}_{8 \mathrm{H}}(8-5) \mathrm{T}_{6 \mathrm{OH}^{-}} 3^{\prime}$, formation of the $5^{\prime}-\mathrm{T}_{6 \mathrm{OH}}(5-8)\left({ }^{\circ} \mathrm{G}_{8 \mathrm{H}}\right)-3^{\prime}$ adduct may greatly influence the local DNA structure due to the essential conformational adjustment.

Among the five addition steps investigated above, the $3^{\prime} \mathrm{G} / \mathrm{C}_{8}$ addition of the ${ }^{\mathrm{T}_{6 \mathrm{OH}}}$ radical has the relatively lowest free energy barrier (14.74 kcal mol${ }^{-1}$, Table 1), and the reaction free energy is calculated to be $2.40 \mathrm{kcal} \mathrm{mol}^{-1}$, comparable to and $3.41 \mathrm{kcal} \mathrm{mol}^{-1}$ smaller than those for the $3^{\prime} \mathrm{G} / \mathrm{C}_{8}$ addition step of the ${ }^{\circ} \mathrm{U}_{\mathrm{CH}_{2}}$ radical and the $5^{\prime} \mathrm{G} / \mathrm{C}_{8}$ addition of the ${ }^{\circ} \mathrm{T}_{6 \mathrm{OH}}$ radical, respectively. But it does not suggest that the yield of the $\mathrm{T}_{6 \mathrm{OH}}(5-$ 8)G intrastrand cross-link is larger than those of the $T(5 \mathrm{~m}-8) \mathrm{G}$ and $\mathrm{G}(8-5) \mathrm{T}_{6 \mathrm{OH}}$ intrastrand cross-links. As listed in Table 1 , a thermodynamic free energy requirement as high as $18.23 \mathrm{kcal} \mathrm{mol}^{-1}$ is estimated for the essential conformational adjustment, making the reaction free energy for the $3^{\prime} \mathrm{G} / \mathrm{C}_{8}$ addition of the ${ }^{\cdot} \mathrm{T}_{6 \mathrm{OH}}$ radical increased to $20.63 \mathrm{kcal} \mathrm{mol}^{-1}$, 
separately ca. $9 \mathrm{kcal} \mathrm{mol}^{-1}$ and $15 \mathrm{kcal} \mathrm{mol}^{-1}$ higher than those for the $3^{\prime} \mathrm{G} / \mathrm{C}_{8}$ addition of the ${ }^{\prime} \mathrm{U}_{\mathrm{CH}_{2}}$ radical and the $5^{\prime} \mathrm{G} / \mathrm{C}_{8}$ addition of the ${ }^{\circ} \mathrm{T}_{6 \mathrm{OH}}$ radical. Thus, although formation of the $5^{\prime}-\mathrm{T}_{6 \mathrm{OH}}(5-8)\left({ }^{\circ} \mathrm{G}_{8 \mathrm{H}}\right)-3^{\prime}$ adduct is thermodynamically feasible when taking into account the preceding step of formation of the canonical $5^{\prime}-\left({ }^{\circ} \mathrm{T}_{6 \mathrm{OH}}\right) \mathrm{G}-3^{\prime}$ sequence and the subsequent step of formation of the closed-shell $5^{\prime}-\mathrm{T}_{6 \mathrm{OH}}(5-8) \mathrm{G}-3^{\prime}$ cross-link (Fig. S8 and S9 in the ESI, $\uparrow$ the driving forces are separately estimated to be -29.13 and $-82.68 \mathrm{kcal} \mathrm{mol}^{-1}$ ), the thermodynamically more unfavourable conformational adjustment indicates that the formation efficiency of the $5^{\prime}-\mathrm{T}_{6 \mathrm{OH}}(5-8)\left({ }^{\circ} \mathrm{G}_{8 \mathrm{H}}\right)-3^{\prime}$ adduct is much lower than those of the $5^{\prime}-{ }^{-} \mathrm{G}_{8 \mathrm{H}}(8-5) \mathrm{T}_{6 \mathrm{OH}^{-3}}{ }^{\prime}$ and $5^{\prime}-\mathrm{T}(5 \mathrm{~m}-$ 8) $\left({ }^{\circ} \mathrm{G}_{8 \mathrm{H}}\right)-3^{\prime}$ adducts, which may explain why the yield of the corresponding $\mathrm{T}_{6 \mathrm{OH}}(5-8) \mathrm{G}$ intrastrand cross-link is much less than those of the $\mathrm{G}(8-5) \mathrm{T}_{6 \mathrm{OH}}$ and $\mathrm{T}(5 \mathrm{~m}-8) \mathrm{G}$ intrastrand crosslinks. ${ }^{15,23}$

The reaction path of the ${ }^{\circ} \mathrm{C}_{6 \mathrm{OH}}$ radical addition to the $\mathrm{C}_{8}$ site of its $3^{\prime}$ neighboring deoxyguanosine is found to be nearly the same as that of the $3^{\prime} \mathrm{G} / \mathrm{C}_{8}$ addition of the ${ }^{\circ} \mathrm{T}_{6 \mathrm{OH}}$ radical (Fig. 6). An essential conformational adjustment involving orientation transitions of both nucleobase moieties and twist of DNA backbone with alterations of the related torsion angles (Table 2) comparable to those observed in the $3^{\prime} \mathrm{G} / \mathrm{C}_{8}$ addition of the ${ }^{\cdot} \mathrm{T}_{6 \mathrm{OH}}$ radical is firstly required, which makes the configuration of thus formed intermediate (denoted as $\mathrm{INT}_{\mathrm{CG}}$ ) much analogous to that of the intermediate $\mathrm{INT}_{\mathrm{TG}}$. The distance $d_{\mathrm{G} / \mathrm{Cg}-\mathrm{C} / \mathrm{C} 5}$ that is lowered to $3.12 \AA$ in the intermediate $\mathrm{INT}_{\mathrm{CG}}$ is decreased to $2.20 \AA$ in the located transition state (denoted as $\mathrm{TS}_{\mathrm{CG}}$ ), and eventually reduced to $1.58 \AA$ forming a standard C-C single
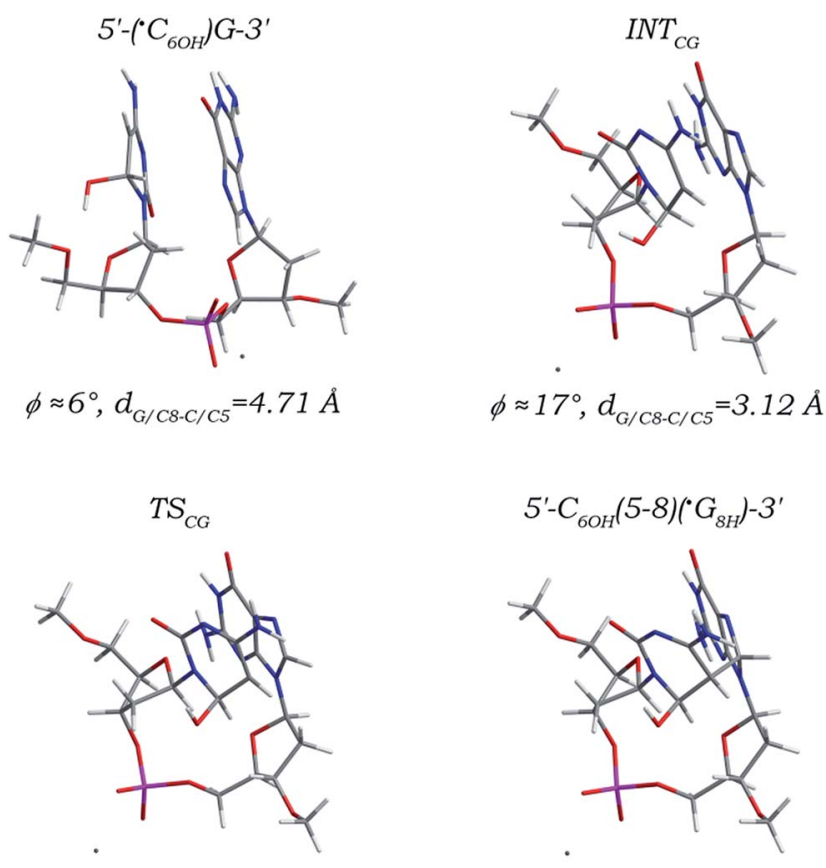

$$
\phi \approx 24^{\circ}, d_{G / C 8-C / C 5^{2}}=2.20 \AA
$$

$$
5^{\prime}-C_{6 O H}(5-8)\left(\cdot G_{8 H}\right)-3^{\prime}
$$

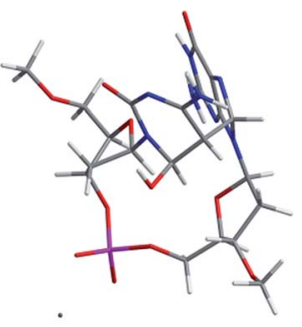

$\phi \approx 37^{\circ}, d_{G / C 8-C / C 5}=1.58 \AA$

Fig. 6 Optimized structures and partial structural parameters for stationary points along the reaction path of the ${ }^{\circ} \mathrm{C}_{6 \mathrm{OH}}$ radical addition to the $\mathrm{C}_{8}$ site of its $3^{\prime}$ neighboring deoxyguanosine. bond in the addition product (denoted as $\left.5^{\prime}-\mathrm{C}_{6 \mathrm{OH}}(5-8)\left({ }^{\circ} \mathrm{G}_{8 \mathrm{H}}\right)-3^{\prime}\right)$. Changes of the $\mathrm{C}_{5}-\mathrm{C}_{4}$ and $\mathrm{C}_{5}-\mathrm{C}_{6}$ bonds in the $5^{\prime}{ }^{\cdot} \mathrm{C}_{6 \mathrm{OH}}$ moiety and the $\mathrm{C}_{8}-\mathrm{N}_{7}$ and $\mathrm{C}_{8}-\mathrm{N}_{9}$ bonds in the $3^{\prime} \mathrm{dG}$ moiety as well as the other bonds are demonstrated to be nearly the same as those observed in the corresponding $5^{\prime} \mathrm{G} / \mathrm{C}_{8}$ addition. The increment of the angle $\phi$ along the reaction path is relatively small $\left(31^{\circ}\right)$, but as in the cases of the $3^{\prime} \mathrm{G} / \mathrm{C}_{8}$ additions of the ${ }^{\prime} \mathrm{U}_{\mathrm{CH}_{2}}$ and ${ }^{\circ} \mathrm{T}_{6 \mathrm{OH}}$ radicals, the prerequisite conformational transformation also makes formation of the adduct $5^{\prime}-\mathrm{C}_{6 \mathrm{OH}}(5-$ $8)\left({ }^{\circ} G_{8 \mathrm{H}}\right)-3^{\prime}$ give rise to substantial effects on the local DNA structure. Kinetically, the activation free energy (10.79 kcal mol ${ }^{-1}$, Table 1) for the step of the ${ }^{{ }} \mathrm{C}_{6 \mathrm{OH}}$ radical addition to the $\mathrm{C}_{8}$ site of its $3^{\prime}$ neighboring deoxyguanosine is ca. $4.5 \mathrm{kcal} \mathrm{mol}^{-1}$ smaller than that for the $5^{\prime} \mathrm{G} / \mathrm{C}_{8}$ addition. Thermodynamically, a negative reaction free energy $\left(-5.13 \mathrm{kcal} \mathrm{mol}^{-1}\right)$ is estimated for the $3^{\prime} \mathrm{G} / \mathrm{C}_{8}$ addition step, but the sizably positive free energy requirement for the essential conformational adjustment $\left(17.06 \mathrm{kcal} \mathrm{mol}^{-1}\right)$ makes the reaction free energy estimated from the canonical $5^{\prime}-\left({ }^{\circ} \mathrm{C}_{6 \mathrm{OH}}\right) \mathrm{G}-3^{\prime}$ sequence increased to $11.94 \mathrm{kcal} \mathrm{mol}{ }^{-1}$, which is ca. $11 \mathrm{kcal} \mathrm{mol}^{-1}$ larger than that for the $5^{\prime} \mathrm{G} / \mathrm{C}_{8}$ addition. Thus, as in the case of the $3^{\prime} \mathrm{G} / \mathrm{C}_{8}$ addition of the ${ }^{\top} \mathrm{T}_{6 \mathrm{OH}}$ radical, although formation of the $5^{\prime}-\mathrm{C}_{6 \mathrm{OH}}(5-8)\left({ }^{\circ} \mathrm{G}_{8 \mathrm{H}}\right)-3^{\prime}$ adduct is thermodynamically feasible when coupled with the preceding step of formation of the canonical $5^{\prime}-\left({ }^{\circ} \mathrm{C}_{6 \mathrm{OH}}\right) \mathrm{G}-3^{\prime}$ sequence and the subsequent step of formation of the closed-shell $5^{\prime}-\mathrm{C}(5-8) \mathrm{G}-3^{\prime}$ cross-link (Fig. S8 and S9 in the ESI, $\dagger-21.26$ and $-102.61 \mathrm{kcal} \mathrm{mol}^{-1}$ reaction free energies are calculated, respectively), the formation efficiency of which is much lower than that of its sequence isomer $5^{\prime}-\mathrm{G}_{8 \mathrm{H}}(8-5) \mathrm{C}_{6 \mathrm{OH}^{-3}}{ }^{\prime}$.

In short, different from the simple direct one-step $5^{\prime} \mathrm{G} / \mathrm{C}_{8}$ additions, structurally significant and thermodynamically markedly unfavourable conformational adjustments involving orientation transitions of nucleobase moieties and twist of DNA backbone are essential for the $3^{\prime} \mathrm{G} / \mathrm{C}_{8}$ additions of the ${ }^{-} \mathrm{U}_{\mathrm{CH}_{2}}$, ${ }^{\cdot} \mathrm{T}_{6 \mathrm{OH}}$, and ${ }^{\cdot} \mathrm{C}_{6 \mathrm{OH}}$ radicals. Notably, in double helical DNA, the stabilizing interactions (including hydrogen bonds and basestacking arrangements) may penalize, to a larger extent, these conformational transformations, making the $3^{\prime} \mathrm{G} / \mathrm{C}_{8}$ additions of the ${ }^{\circ} \mathrm{U}_{\mathrm{CH}_{2}},{ }^{\circ} \mathrm{T}_{6 \mathrm{OH}}$, and ${ }^{\circ} \mathrm{C}_{6 \mathrm{OH}}$ radicals even more unpreferred. Such essential conformational transformations may thus be the reasons leading to the differences in the formation yields and biological significance of the $\mathrm{G}(8-5 \mathrm{~m}) \mathrm{T} / \mathrm{G}(8-5) \mathrm{T}_{6 \mathrm{OH}} / \mathrm{G}(8-5) \mathrm{C}$ and $\mathrm{T}(5 \mathrm{~m}-8) \mathrm{G} / \mathrm{T}_{6 \mathrm{OH}}(5-8) \mathrm{G} / \mathrm{C}(5-8) \mathrm{G}$ intrastrand cross-links. In addition, the more unfavourable thermodynamic requirement for the prerequisite conformational transformation along the $3^{\prime} \mathrm{G} /$ $\mathrm{C}_{8}$ addition path of the ${ }^{\circ} \mathrm{T}_{6 \mathrm{OH}}$ radical may provide a plausible explanation for the observation that the yield of the $\mathrm{T}_{6 \mathrm{OH}}(5-8) \mathrm{G}$ intrastrand cross-link is much lower than that of the $\mathrm{T}(5 \mathrm{~m}-8) \mathrm{G}$ intrastrand cross-link.

\section{Conclusions}

Reaction mechanisms of the ${ }^{\circ} \mathrm{U}_{\mathrm{CH}_{2}},{ }^{\circ} \mathrm{T}_{6 \mathrm{OH}}$, and ${ }^{\circ} \mathrm{C}_{6 \mathrm{OH}}$ radicals separately adding to the $\mathrm{C}_{8}$ site of their $3^{\prime}$ and $5^{\prime}$ neighboring deoxyguanosines are investigated in the present work. It is found that additions of all these three radicals to the $\mathrm{C}_{8}$ site of 
their $5^{\prime}$ neighboring deoxyguanosines are straightforward onestep reactions, and along each addition path only relatively minor structural alterations are induced with both nucleobase moieties always maintaining the anti-orientations. In contrast, additions of the ${ }^{\circ} \mathrm{U}_{\mathrm{CH}_{2}},{ }^{\cdot} \mathrm{T}_{6 \mathrm{OH}}$, and ${ }^{\circ} \mathrm{C}_{6 \mathrm{OH}}$ radicals to the $\mathrm{C}_{8}$ site of their $3^{\prime}$ neighboring deoxyguanosines are rather complex. The canonical $5^{\prime}-\left({ }^{\circ} \mathrm{U}_{\mathrm{CH}_{2}}\right) \mathrm{G}-3^{\prime}, \quad 5^{\prime}-\left({ }^{\cdot} \mathrm{T}_{6 \mathrm{OH}}\right) \mathrm{G}-3^{\prime}$, and $5^{\prime}-\left({ }^{\cdot} \mathrm{C}_{6 \mathrm{OH}}\right) \mathrm{G}-3^{\prime}$ sequences must be firstly transformed into certain intermediates, during which the anti-orientations of the two nucleobase moieties are translated to syn-(for the $5^{\prime}$ nucleobase) and (near) T-shaped orientations (for the $3^{\prime} \mathrm{dG}$ ) and the DNA backbone are twisted around the $\mathrm{C}_{3^{\prime}}-\mathrm{O}_{3^{\prime}}, \mathrm{O}_{3^{\prime}}-\mathrm{P}, \mathrm{P}-\mathrm{O}_{5^{\prime}}$, and $\mathrm{C}_{5^{\prime}}-\mathrm{O}_{5^{\prime}}$ bonds, respectively. Compared to the simple direct $5^{\prime} \mathrm{G} / \mathrm{C}_{8}$ additions, such significant conformational adjustments along the $3^{\prime} \mathrm{G} / \mathrm{C}_{8}$ addition paths may greatly influence the local DNA structure, and thus may give rise to distinctively different biological significance of the corresponding intrastrand cross-links. On the other hand, greatly positive reaction free energies are estimated for these prerequisite conformational transformations, making the total driving forces for $3^{\prime} \mathrm{G} / \mathrm{C}_{8}$ additions 10 $15 \mathrm{kcal} \mathrm{mol}^{-1}$ larger than those for $5^{\prime} \mathrm{G} / \mathrm{C}_{8}$ additions. Furthermore, such essential conformational adjustments may be disfavoured, to a larger extent, in double-stranded DNA due to existence of the stabilizing interactions from hydrogen bonds and base-stacking arrangements. Combined, the $3^{\prime} \mathrm{G} / \mathrm{C}_{8}$ additions of the ${ }^{\circ} \mathrm{U}_{\mathrm{CH}_{2}},{ }^{\circ} \mathrm{T}_{6 \mathrm{OH}}$, and ${ }^{\cdot} \mathrm{C}_{6 \mathrm{OH}}$ radicals are thus both structurally and thermodynamically significantly more unfavourable than the corresponding $5^{\prime} \mathrm{G} / \mathrm{C}_{8}$ additions, which may be the reasons why the yields of the $5^{\prime}$-pyrimidine-purine- $3^{\prime}$ cross-links are obviously lower than those of the $5^{\prime}$-purinepyrimidine-3' cross-links. All results reported here provide a plausible explanation for the sequence effect observed both in the formation yields and biological significance of pyrimidinetype radicals induced DNA intrastrand cross-links.

\section{Conflicts of interest}

There are no conflicts to declare.

\section{Acknowledgements}

This work was supported by China Postdoctoral Science Foundation (No. 2016M602455), National Natural Science Foundation of China (No. 21375016, 21475022, and 21505019), Natural Science Foundation of Guangdong Province (No. 2015A030310272), Technology Planning Project of Guangdong Province (No. 2015B090927007), and Guangdong Provincial Key Platform and Major Scientific Research Projects for Colleges and Universities (No. 2014KZDXM073, 2015KCXTD029, 2016KTSCX136, 2016KTSCX135, and 2016KQNCX166), and Research Start-up Funds of DGUT (GC300501-04).

\section{Notes and references}

1 J. Prousek, Pure Appl. Chem., 2007, 79, 2325.

2 B. G. Ershov and A. V. Gordeev, Radiat. Phys. Chem., 2008, 77, 928.
3 S. Steenken, Chem. Rev., 1989, 89, 503.

4 M. D. Evans, M. Dizdaroglu and M. S. Cooke, Mutat. Res., 2004, 567, 1.

5 Y. Wang, Chem. Res. Toxicol., 2008, 21, 276.

6 T. Finkel and N. J. Holbrook, Nature, 2000, 408, 239.

7 M. A. Lovell, S. Soman and M. A. Bradley, Mech. Ageing Dev., 2011, 132, 443.

8 K. Satoh, B. C. Berk and H. Shimokawa, Nitric Oxide, 2011, 25, 211.

9 T. B. Kryston, A. B. Georgiev, P. Pissis and A. G. Georgakilas, Mutat. Res., 2011, 711, 193.

10 A. Kotsinas, V. Aggarwal, E. J. Tan, B. Levy and V. G. Gorgoulis, Cancer Lett., 2012, 327, 97.

11 H. C. Box, E. E. Budzinski, J. D. Dawidzik, J. C. Wallace, M. S. Evans and J. S. Gobey, Radiat. Res., 1996, 145, 641.

12 H. C. Box, E. E. Budzinski, J. B. Dawidzik, J. S. Gobey and H. G. Freund, Free Radical Biol. Med., 1997, 23, 1021.

13 H. C. Box, E. E. Budzinski, J. B. Dawidzik, J. C. Wallace and H. Iijima, Radiat. Res., 1998, 149, 433.

14 H. C. Box, H. B. Patrzyc, J. B. Dawidzik, J. C. Wallace, H. G. Freund, H. Iijima and E. E. Budzinski, Radiat. Res., 2000, 153, 442.

15 S. Bellon, J. L. Ravanat, D. Gasparutto and J. Cadet, Chem. Res. Toxicol., 2002, 15, 598.

16 C. Gu and Y. Wang, Biochemistry, 2004, 43, 6745.

17 H. Hong, H. Cao, Y. Wang and Y. Wang, Chem. Res. Toxicol., 2006, 19, 614.

18 Y. Jiang, H. Hong, H. Cao and Y. Wang, Biochemistry, 2007, 46, 12757.

19 H. Hong, H. Cao and Y. Wang, Nucleic Acids Res., 2007, 35, 7118.

20 H. Cao and Y. Wang, Nucleic Acids Res., 2007, 35, 4833.

21 L. C. Colis, P. Raychaudhury and A. K. Basu, Biochemistry, 2008, 47, 8070.

22 J. Wang, H. Cao, C. You, B. Yuan, R. Bahde, S. Gupta, C. Nishigori, L. J. Niedernhofer, P. J. Brooks and Y. Wang, Nucleic Acids Res., 2012, 40, 7368.

23 H. B. Patrzyc, J. B. Dawidzik, E. E. Budzinski, H. G. Freund, J. H. Wilton and H. C. Box, Radiat. Res., 2012, 178, 538.

24 A. Romieu, S. Bellon, D. Gasparutto and J. Cadet, Org. Lett., 2000, 2, 1085.

25 S. Bellon, D. Gasparutto, A. Romieu and J. Cadet, Nucleosides, Nucleotides Nucleic Acids, 2001, 20, 967.

26 Q. Zhang and Y. Wang, J. Am. Chem. Soc., 2003, 125, 12795. 27 Q. Zhang and Y. Wang, J. Am. Chem. Soc., 2004, 126, 13287. 28 Y. Zeng and Y. Wang, J. Am. Chem. Soc., 2004, 126, 6552.

29 Q. Zhang and Y. Wang, Nucleic Acids Res., 2005, 33, 1593.

30 H. Hong and Y. Wang, J. Am. Chem. Soc., 2005, 127, 13969.

31 Y. Zeng and Y. Wang, Nucleic Acids Res., 2006, 34, 6521.

32 Y. Zeng and Y. Wang, Biochemistry, 2007, 46, 8189.

33 G. Lin, J. Zhang, Y. Zeng, H. Luo and Y. Wang, Biochemistry, 2010, 49, 2346.

34 M. Dizdaroglu and P. Jaruga, Free Radical Res., 2012, 46, 382. 35 S. Bellon, D. Gasparutto, C. Saint-Pierre and J. Cadet, Org. Biomol. Chem., 2006, 4, 3831.

36 Q. Zhang and Y. Wang, Chem. Res. Toxicol., 2005, 18, 1897. 37 C. Gu and Y. Wang, Biochemistry, 2005, 44, 8883. 
38 P. Raychaudhury and A. K. Basu, Biochemistry, 2011, 50, 2330.

39 Z. Yang, L. C. Colis, A. K. Basu and Y. Zou, Chem. Res. Toxicol., 2005, 18, 1339.

40 C. Gu, Q. Zhang, Z. Yang, Y. Wang, Y. Zou and Y. Wang, Biochemistry, 2006, 45, 10739.

41 J. Garrec, C. Patel, U. Rothlisberger and E. Dumont, J. Am. Chem. Soc., 2012, 134, 2111.

42 E. Dumont, T. Dršata, C. F. Guerra and F. Lankaš, Biochemistry, 2015, 54, 1259.

43 V. Labet, C. Morell, A. Grand, J. Cadet, P. Cimino and V. Barone, Org. Biomol. Chem., 2008, 6, 3300.

44 C. D. M. Churchill, L. A. Eriksson and S. D. Wetmore, Chem. Res. Toxicol., 2011, 24, 2189.

45 C. Dupont, C. Patel and E. Dumont, J. Phys. Chem. B, 2011, 115, 15138.

46 C. Patel, J. Garrec, C. Dupont and E. Dumont, Biochemistry, 2013, 52, 425.

47 J. Garrec and E. Dumont, Chem. Res. Toxicol., 2014, 27, 1133. 48 C. D. M. Churchill, L. A. Eriksson and S. D. Wetmore, J. Phys. Chem. B, 2016, 120, 1195.

49 J. Gu, J. Wang and J. Leszczynski, Nucleic Acids Res., 2010, 38, 5280.

50 C. D. M. Churchill and S. D. Wetmore, Phys. Chem. Chem. Phys., 2011, 13, 16373.

51 J. P. Cerón-Carrasco, D. Jacquemin and E. Dumont, J. Phys. Chem. B, 2013, 117, 16397.
52 G. Scalmania and M. J. Frisch, J. Phys. Chem. B, 2010, 132, 114110.

53 M. J. Frisch, G. W. Trucks, H. B. Schlegel, G. E. Scuseria, M. A. Robb, J. R. Cheeseman, G. Scalmani, V. Barone, B. Mennucci, G. A. Petersson, H. Nakatsuji, M. Caricato, X. Li, H. P. Hratchian, A. F. Izmaylov, J. Bloino, G. Zheng, J. L. Sonnenberg, M. Hada, M. Ehara, K. Toyota, R. Fukuda, J. Hasegawa, M. Ishida, T. Nakajima, Y. Honda, O. Kitao, H. Nakai, T. Vreven, J. A. Montgomery Jr, J. E. Peralta, F. Ogliaro, M. Bearpark, J. J. Heyd, E. Brothers, K. N. Kudin, V. N. Staroverov, T. Keith, R. Kobayashi, J. Normand, K. Raghavachari, A. Rendell, J. C. Burant, S. S. Iyengar, J. Tomasi, M. Cossi, N. Rega, J. M. Millam, M. Klene, J. E. Knox, J. B. Cross, V. Bakken, C. Adamo, J. Jaramillo, R. Gomperts, R. E. Stratmann, O. Yazyev, A. J. Austin, R. Cammi, C. Pomelli, J. W. Ochterski, R. L. Martin, K. Morokuma, V. G. Zakrzewski, G. A. Voth, P. Salvador, J. J. Dannenberg, S. Dapprich, A. D. Daniels, O. Farkas, J. B. Foresman, J. V. Ortiz, J. Cioslowski and D. J. Fox, Gaussian 09, Revision E.01, Gaussian, Inc., Wallingford CT, 2013.

54 X. J. Lu, H. J. Bussemaker and W. K. Olson, Nucleic Acids Res., 2015, 43, e142.

55 A. J. Cohen, P. Mori-Sánchez and W. Yang, Chem. Rev., 2012, 112, 289.

56 H. C. Box, J. B. Dawidzik and E. E. Budzinski, Free Radical Biol. Med., 2001, 31, 856. 